\title{
Socioeconomic, regional and demographic factors related to population ageing
}

Laércio Almeida de Melo'

Lidiane Maria de Brito Macedo Ferreira' Marquiony Marques dos Santos'

Kenio Costa de Lima

\section{Abstract}

Objective: the present study aims to investigate the association between population ageing in municipal regions in the state of Rio Grande do Norte, and socioeconomic, demographic and regional factors. Method: an ecological study that used municipal regions of the state of Rio Grande do Norte as a unit of analysis was carried out. Data collection was conducted through databases from the Brazilian Institute of Geography and Statistics, the Institute of Applied Economic Research and the Atlas of Human Development. The factor of Increased Age was created based on factor analysis, which was related to socioeconomic, demographic and regional variables. The chi-squared test with a significance level of $5 \%$ was used in addition to the Hosmer and Lemeshow technique for logistic regression. Result: it was found that municipal regions in the Central mesoregion have an older/ ageing population, while those with intermediate populations have the oldest individuals. Furthermore, it was found that municipal regions with unequal income distribution and higher levels of education have an older population. Conclusion: it can be concluded that municipal regions classified as older/more aged were associated with the mesoregion to which the municipal region belongs; and those with intermediate population size were associated with favorable educational levels and unequal income distribution.

\footnotetext{
Universidade Federal do Rio Grande do Norte, Departamento de Odontologia. Natal, Rio Grande do Norte, Brasil.

Keywords: Aging. Socioeconomic Factors. Demography. 


\section{INTRODUCTION}

Population aging is a new challenge in today's world. This process has occurred in both developed and developing countries, and its origins lie in socioeconomic transformations in developed nations in the nineteenth century. Significant changes in demographic variables in such countries were only identified at the turn of the twentieth century, however. In developing countries, social inequalities have led to the aging process being more rapid and unstructured ${ }^{1-4}$.

The number of older people in Brazil rose from three million in 1960 to 20 million in 2008, an increase of almost $700 \%$ in less than 50 years ${ }^{5}$. The main determining factor of the phenomenon of demographic aging is fecundity, followed by mortality. However, migration is also a variable that cannot be dispensed with or disregarded in the analysis of this process, especially in the planning and elaboration of public policies aimed at the elderly ${ }^{6}$.

The processes of demographic and epidemiological transition in Brazil are clearly heterogeneous and are associated, in large part, with the inequality of the country's social conditions. The elderly represent a highly differentiated population, both among themselves and in relation to other age groups, in terms of social conditions and demographic and epidemiological aspects? ${ }^{7}$.

These changes directly reflect the way of life of the elderly and the extent to which the same depends on the socio-economic situation of family members. Accidents and urban violence, statistics that were until very recently restricted to young people, are today considered as causes of death among the elderly. Cultural indicators, in turn, show that elderly persons today are much more immersed in social events, literate and well informed ${ }^{8}$.

It is known that education, income, nutrition and lifestyle are potential determinants of longevity. These factors are usually dependent on the care of relatives or even society?. However, it is not enough to offer the elderly individual extra years of life, without such years being accompanied by dignified living conditions ${ }^{5}$.
In the state of Rio Grande do Norte the reality is no different from the rest of Brazil, with an increase in the number of elderly people. Data from the IBGE census showed that $8.2 \%$ of the population were over 60 years old in 1991, with this percentage rising to $9 \%$ in the year 2000 and increasing to $9.25 \%$ in the population count of $2010^{10}$.

The present study therefore aims to investigate the aging profile of the state of Rio Grande do Norte, Brazil, and its association with regional, demographic and socioeconomic factors.

\section{METHODS}

An ecological study was carried out based on data from the databases of the Instituto de Pesquisa Econômica Aplicada (the Institute of Applied Economic Research) (IPEA), the Instituto Brasileiro de Geografia e Estatística (the Brazilian Institute of Geography and Statistics) (IBGE), and the Human Development Atlas. Sixty-one of the 167 municipal regions of the state of Rio Grande do Norte were considered, except for the relatively recently created region of Jundiá, for which not all the data used in the analysis was available. Following the removal of the outliers (Frutuoso Gomes, Maxaranguape and Natal), the final sample was 163 municipal regions.

In order to evaluate the aging indicators the following data were collected from the IBGE site for the year 2011: data on elderly dependence (elderly population /number of individuals aged 15-59 years), the aging index (elderly population/number of Individuals aged 1-14 years), active age population replacement rate (elderly population/number of individuals aged 15-19 years), percentage of elderly persons (elderly population/total population), over aging (population aged 80 years old or over/elderly population X 100) and extreme old age (population aged over 90/elderly population X 100). From these last three the "Increased Age" factor was created, in the form of a factorial, with the factor extraction method based on analysis of the main components. Increased Age was considered the dependent variable of the study.

For the evaluation of socioeconomic, demographic and regional aspects, the indicators used were: 
mesoregion to which the municipal region belongs; Rate of Urbanization; Total population of municipal region; Theil, Human Development Index (HDI) income and education; Rate of participation of economically active population in the labor market; Victims of accidents rate; Homicide rate; Firjan Municipal Development Index (FMDI) employment and income; education and health; Illiteracy rate; Literacy rate; Percentage of poverty; Gender ratio; Mean years of study of people aged 25 years and over; Household income per capita - $1^{\text {st }}$ quintile; Household income per capita - $5^{\text {th }}$ quintile and Gini Index ${ }^{11,12}$, collected from the Human Development Atlas and the IPEA website, for the year 2000. The data refer to the year 2000 as it is believed that the changes in the economy, society and demography of the previous decade represent a real interference in the current society, as a reflection of the previous years.
The association between socioeconomic, demographic and regional variables and the outcome of Increased Age was verified using the chi-squared test with a confidence level of $95 \%$. The magnitude of effect of the associations was measured by the odds ratio, and for logistic regression, the Hosmer and Lemeshow technique.

\section{RESULTS}

A total of 166 municipal regions in the state of Rio Grande do Norte were evaluated, distributed into the Agreste (42), Central (37), West (62) and Coastal (25) mesoregions. Table 1 shows the descriptive statistics of the independent contextual variables, in relation to the phenomenon of aging in the municipal regions of Rio Grande do Norte.

Table 1. Mean and standard-deviation of study variables. Natal, Rio Grande do Norte, 2014.

\begin{tabular}{ll}
\hline Variable & Mean \\
\hline Urbanization Rate & $0.626( \pm 0.187)$ \\
Total population & $19.062 .921( \pm 67.148 .051)$ \\
Theil & $0.489( \pm 0.085)$ \\
HDI income & $0.522( \pm 0.050)$ \\
HDI education & $0.710( \pm 0.051)$ \\
Participation rate & $0.456( \pm 0.067)$ \\
Victim of accidents rate & $13.507( \pm 17.309)$ \\
Murder rate & $6.869( \pm 11.034)$ \\
FMDI employment and income & $0.260( \pm 0.126)$ \\
FMDI education & $0.502( \pm 0.085)$ \\
FMDI health & $0.561( \pm 0.080)$ \\
Illiterate population & $34.689( \pm 6.910)$ \\
Literacy rate & $65.313( \pm 6.909)$ \\
Poverty percentage & $65.874( \pm 10.458)$ \\
Gender ratio & $1.007( \pm 0.040)$ \\
Years of study (mean among people aged 25 years or more) & $3.439( \pm 0.776)$ \\
Household income per capita (mean of $1^{\text {st }}$ quintile) & $7.778( \pm 8.480)$ \\
Household income per capita (mean of $5^{\text {th }}$ quintile) & $281.993( \pm 118.854)$ \\
Gini & $0.577( \pm 0.045)$ \\
\hline
\end{tabular}

HDI: Human Development Index; FMDI: FIRJAN Municipal Development Index 
Based on the data presented, it can be seen that, on average, the municipal regions of the state of Rio Grande do Norte are poorly populated, with a larger urban than rural population. The population is poor, with little schooling, and there are equal percentages of men and women.

Factorial analysis, with factor extraction based on principal components analysis $(\mathrm{KMO}=0.666$ and Bartlett sphericity test Bartlett $-p<0.001)$, produced a single factor that explained $74.06 \%$ of the variation of all variables remaining in the model. This single factor was called Increased Age and corresponded to the variables percentage of elderly in the population, over-aging and extreme old age. The factor produced explained $67.8 \%, 73.9 \%$ and $80.5 \%$, respectively, of the variance of each of these variables, and its distribution revealed low values for most municipal regions in coastal areas.

Table 2 shows the association of the contextual variables with the Increased Age factorial variable, with notable results for those variables whose association was statistically significant.

Table 2. Association between Increased Age, categorized by the median and socioeconomic, demographic and regional variables. Natal, Rio Grande do Norte, 2014.

\begin{tabular}{|c|c|c|c|c|c|}
\hline Variable & $\begin{array}{l}\text { More elderly } \\
\mathrm{n}(\%)\end{array}$ & $\begin{array}{l}\text { Less elderly } \\
\mathrm{n}(\%)\end{array}$ & PR & CI 95\% & $P$ \\
\hline \multicolumn{6}{|l|}{ Mesoregion } \\
\hline Coastal & $2(8.7 \%)$ & $21(91.3 \%)$ & 1.00 & - & $<0.001$ \\
\hline Agreste & $22(52.4 \%)$ & $20(47.6 \%)$ & 0.17 & $0.04-0.64$ & \\
\hline Central & $25(67.6 \%)$ & $12(32.4 \%)$ & 0.13 & $0.03-0.49$ & \\
\hline West & $34(55.7 \%)$ & $27(44.3 \%)$ & 0.16 & $0.04-0.60$ & \\
\hline \multicolumn{6}{|c|}{ Urbanization Rate } \\
\hline 0.127 to 0.639 & $41(50.0 \%)$ & $41(50.0 \%)$ & 0.96 & $0.71-1.30$ & 0.813 \\
\hline 0.640 to 1.0 & $42(51.9 \%)$ & $39(48.1 \%)$ & & & \\
\hline \multicolumn{6}{|l|}{ Theil } \\
\hline 0.34 to 0.471 & $46(55.4 \%)$ & $37(44.6 \%)$ & 1.20 & $0.88-1.63$ & 0.242 \\
\hline 0.472 to 0.937 & $37(46.3 \%)$ & $43(53.8 \%)$ & & & \\
\hline \multicolumn{6}{|l|}{ HDI (Income) } \\
\hline 0.395 to 0.514 & $43(51.2 \%)$ & $41(48.8 \%)$ & 1.01 & $0.75-1.37$ & 0.943 \\
\hline 0.515 to 0.746 & $40(50.6 \%)$ & $39(49.4 \%)$ & & & \\
\hline \multicolumn{6}{|c|}{ HDI (Education) } \\
\hline 0.59 to 0.705 & $43(50.6 \%)$ & $42(49.4 \%)$ & 0.97 & $0.53-1.80$ & 0.929 \\
\hline 0.706 to 0.887 & $40(51.3 \%)$ & $38(48.7 \%)$ & & & \\
\hline \multicolumn{6}{|c|}{ Participation rate } \\
\hline 0.220 to 0.454 & $42(50.6 \%)$ & $41(49.4 \%)$ & 0.99 & $0.73-1.33$ & 0.934 \\
\hline 0.455 to 0.67 & $41(51.3 \%)$ & $39(48.8 \%)$ & & & \\
\hline \multicolumn{6}{|c|}{ Victims of accidents rate } \\
\hline 8.745 to 109.17 & $47(58.0 \%)$ & $34(42.0 \%)$ & 1.32 & $0.97-1.80$ & 0.071 \\
\hline 0.00 to 8.744 & $36(43.9 \%)$ & $46(56.1 \%)$ & & & \\
\hline
\end{tabular}


continued from Table 1

\begin{tabular}{|c|c|c|c|c|c|}
\hline Variable & $\begin{array}{l}\text { More elderly } \\
\mathrm{n}(\%)\end{array}$ & $\begin{array}{l}\text { Less elderly } \\
\mathrm{n}(\%)\end{array}$ & PR & CI 95\% & $P$ \\
\hline \multicolumn{6}{|l|}{ Murder rate } \\
\hline 0 & $56(56.6 \%)$ & $43(43.4 \%)$ & 1.34 & $0.96-1.87$ & 0.073 \\
\hline 0.01 to 56.59 & $27(42.2 \%)$ & $37(57.8 \%)$ & & & \\
\hline \multicolumn{6}{|l|}{ Gini } \\
\hline 0.58 to 0.73 & $44(60.3 \%)$ & $29(39.7 \%)$ & 1.39 & $1.03-1.88$ & 0.031 \\
\hline 0.47 to 0.57 & $39(43.3 \%)$ & $51(56.7 \%)$ & & & \\
\hline \multicolumn{6}{|l|}{ FMDI (Education) } \\
\hline 0.505 to 0.697 & $50(61.7 \%)$ & $31(38.3 \%)$ & 1.53 & $1.12-2.10$ & 0.006 \\
\hline 0.319 to 0.504 & $33(40.2 \%)$ & $49(59.8 \%)$ & & & \\
\hline \multicolumn{6}{|c|}{ FMDI (employment and income) } \\
\hline 0.046 to 0.247 & $50(61.0 \%)$ & $32(39.0 \%)$ & 1.50 & $1.09-2.05$ & 0.010 \\
\hline 0.248 to 0.781 & $33(40.7 \%)$ & $48(59.3 \%)$ & & & \\
\hline \multicolumn{6}{|l|}{ FMDI (health) } \\
\hline 0.386 to 0.54 & $47(56.6 \%)$ & $36(43.4 \%)$ & 1.26 & $0.93-1.71$ & 0.138 \\
\hline 0.55 to 0.772 & $36(45.0 \%)$ & $44(55.0 \%)$ & & & \\
\hline \multicolumn{6}{|l|}{ Illiterate population } \\
\hline 12.2 to 35.34 & $41(51.3 \%)$ & $39(48.8 \%)$ & 1.01 & $0.75-1.37$ & 0.934 \\
\hline 35.35 to 49.40 & $42(50.6 \%)$ & $41(49.4 \%)$ & & & \\
\hline \multicolumn{6}{|l|}{ Literacy rate } \\
\hline 50.56 to 64.654 & $41(49.4 \%)$ & $42(50.6 \%)$ & 0.94 & $0.70-1.27$ & 0.692 \\
\hline 64.655 to 87.84 & $42(52.5 \%)$ & $38(47.5 \%)$ & & & \\
\hline \multicolumn{6}{|l|}{ Gender ratio } \\
\hline 0.89 to 1.003 & $44(55.7 \%)$ & $35(44.3 \%)$ & 1.20 & $0.89-1.62$ & 0.237 \\
\hline 1.004 to 1.11 & $39(46.4 \%)$ & $45(53.6 \%)$ & & & \\
\hline \multicolumn{6}{|l|}{ Years of study } \\
\hline 2.13 to 3.28 & $40(48.2 \%)$ & $43(51.8 \%)$ & 0.90 & $0.66-1.21$ & 0.478 \\
\hline 3.29 to 7.2 & $43(53.8 \%)$ & $37(46.3 \%)$ & & & \\
\hline \multicolumn{6}{|l|}{ Income $1^{\text {st }}$ quintile } \\
\hline 0.0 to 4.7 & $46(55.4 \%)$ & $37(44.6 \%)$ & 1.20 & $0.88-1.63$ & 0.242 \\
\hline 4.8 to 32.86 & $37(46.3 \%)$ & $43(53.8 \%)$ & & & \\
\hline \multicolumn{6}{|l|}{ Income by $5^{\text {th }}$ quintile } \\
\hline 142.55 to 254.087 & $40(48.2 \%)$ & $43(51.8 \%)$ & 0.90 & $0.66-1.21$ & 0.756 \\
\hline 254.088 to 1165.44 & $43(51.8 \%)$ & $40(48.2 \%)$ & & & \\
\hline \multicolumn{6}{|l|}{ Total population } \\
\hline Less Populous & $29(50.8 \%)$ & $28(49.2 \%)$ & 1.00 & - & 0.006 \\
\hline Intermediate Population & $36(65.5 \%)$ & $19(34.5 \%)$ & 1.50 & $1.13-2.01$ & \\
\hline More Populous & $18(33.4 \%)$ & $36(66.6 \%)$ & 0.79 & 0.58-1.09 & \\
\hline
\end{tabular}

HDI: Human Development Index; FMDI: FIRJAN Municipal Development Index 
In the analysis of the variables it was verified that the municipal regions of the Central Mesoregion had older elderly persons than the other regions of the state. There was no significant association between the variables Urbanization Rate, Theil, HDI income, HDI education, labor market participation, Victims of accidents rate, Murder Rate, FMDI Health, Illiterate population, Literacy rate, Gender ratio, Years of study, $1^{\text {st }}$ and $5^{\text {th }}$ quintile income and the Increased Age factor.

With regard to the association between the representative variable of the categorization of the population by terciles, it was found that, when comparing the strata obtained with the stratum of the most populous municipal regions, the municipal regions with an intermediate population had a higher Increased Age factor. In relation to FMDI Education, it was found that individuals with higher levels of education were older than those with unfavorable levels of education.

When the municipal regions of Rio Grande do Norte were stratified according to the values of the FMDI employment and income variables, it was observed that the municipal regions with lower levels of employment and income had older populations than those with higher rates of employment and income. In addition, it was found that municipal regions with unequal income distribution also had an older population.

However, when the variables that presented a significant association underwent logistic regression, there was a loss of statistical significance in relation to the distribution of the Increased Age factor for the indicators FMDI employment and income (Table 3).

Table 3. Comparison of the proportions of the "Increased Age" factor with the socioeconomic, demographic and regional variables, and their gross and adjusted prevalence ratios. Natal, Rio Grande do Norte, 2014.

\begin{tabular}{|c|c|c|c|c|c|c|c|c|}
\hline Variable & $\begin{array}{l}\text { More aged } \\
\mathrm{n}(\%)\end{array}$ & $\begin{array}{l}\text { Less aged } \\
\mathrm{n}(\%)\end{array}$ & PR & CI 95\% & $p$ & PR Ad & CI Ad 95\% & $p^{* *}$ \\
\hline \multicolumn{9}{|l|}{ Mesoregion $2^{*}$} \\
\hline Central & $25(67.6 \%)$ & $12(32.4 \%)$ & 1.47 & $1.10-1.97$ & 0.021 & 1.51 & $1.06-2.16$ & 0.024 \\
\hline Other regions & $58(46.0 \%)$ & $68(54.0 \%)$ & & & & & & \\
\hline \multicolumn{9}{|l|}{ Gini } \\
\hline 0.58 to 0.73 & $44(60.3 \%)$ & $29(39.7 \%)$ & 1.39 & $1.03-1.88$ & 0.031 & 1.44 & $1.02-2.05$ & 0.041 \\
\hline 0.47 to 0.57 & $39(43.3 \%)$ & $51(56.7 \%)$ & & & & & & \\
\hline \multicolumn{9}{|l|}{ FMDI (Education) } \\
\hline 0.505 to 0.697 & $50(61.7 \%)$ & $31(38.3 \%)$ & 1.53 & $1.12-2.10$ & 0.006 & 1.65 & $1.17-2.31$ & 0.004 \\
\hline 0.319 to 0.504 & $33(40.2 \%)$ & $49(59.8 \%)$ & & & & & & \\
\hline \multicolumn{9}{|l|}{ Population $1^{*}$} \\
\hline Intermediate Population & $36(65.5 \%)$ & $19(34.5 \%)$ & 1.50 & $1.13-2.01$ & 0.008 & 1.44 & $1.02-2.02$ & 0.040 \\
\hline Other populations & $47(43.5 \%)$ & $61(56.5 \%)$ & & & & & & \\
\hline
\end{tabular}




\section{DISCUSSION}

The demographic transition experienced by Latin America over the last century has occurred rapidly and belatedly in comparison with developed countries. One of the consequences of this phenomenon is the rapid aging of the population of the region ${ }^{13}$.

This phenomenon is explained by improved survival rates, with declining mortality levels benefiting the elderly population and contributing to population aging, coupled with a rapid and marked reduction in fertility ${ }^{14}$. However, such effects are debated and balanced by other schools of thought ${ }^{13}$, with migration considered to be an important factor for heterogeneous aging among different regions ${ }^{14}$.

Mortality in Brazil has declined since the beginning of the process of industrialization and urbanization following World War II. Added to this is a growing decline in fertility rates in the country since 1960, exacerbated in recent decades. In Rio Grande do Norte, this rate declined from 2.54 children per woman of childbearing age in 2000 to 1.99 in 2010 , a decrease of $21.5 \%$ and below the population replacement level of $2.1^{15,16}$.

Also in relation to mortality and as a consequence of this process of population aging, an increase in the participation in deaths of the population of 70 years or more, which in the 2010 Census was $43.9 \%$, has been noted. In Rio Grande do Norte, the share of deaths of this population segment was the highest among all the states, reaching 50.2\%. The reason for this participation is the emigration of the younger population from the state. Rio Grande do Norte is characterized as an expeller of younger populations, especially those in the 20 to 24 years of age group, resulting in the residence of an older population ${ }^{15}$.

Considering this population dynamic, demographic growth in Brazil has proved to be an important factor in the development of the economy, and improved income distribution, since the economically active population tends to concentrate in urban areas, where labor supply is higher, while the economically inactive population concentrates in less developed localities.
These "demographic inequalities", in turn, may exacerbate social differences ${ }^{17}$, especially in a vulnerable section of the population such as the elderly, historically neglected by the state and in the planning of public policies.

PNAD data reveals an improvement in the health conditions of the elderly in the period between 1998 and 2003, a probable reflection of the increase of their educational level and socioeconomic status, and greater access to health services ${ }^{5}$. This improvement in socioeconomic conditions may reflect, among other things, the growing presence of younger elderly people in the workforce, and the improvement of the economic conditions of the population as a whole, which in turn affects the family economy, in which the elderly play an increasingly important role.

The aging of the Brazilian population is not spatially homogeneous, in part due to migratory movements that tend to rejuvenate populations that receive migrants and age those that lose them ${ }^{14}$.

The Increased Age factor captured all the aging processes of the municipal regions of Rio Grande do Norte, as it contemplated the total aging of the population, as well as the participation of the elderly in the make-up of such populations.

Population migration among municipal regions is an important contributory factor for the aging of the population of the interior of the state, since young people tend to migrate to the capital and more populated cities, where, for the most part, greater economic dynamism is found. These young people seek employment opportunities and better living conditions in such places. In Rio Grande do Norte, this reality is observed in coastal cities, where there is a concentration of younger people and younger elderly persons ${ }^{15}$.

In 2011 in Rio Grande do Norte about 40\% of the population of municipal regions were not born in such regions, while $11 \%$ of the total population of the state were not born within its borders, demonstrating the intense migratory movement that exists in the state ${ }^{15}$.

This results in a more aged population in the rural hinterland, who are also more economically 
inactive, resulting in an uneven distribution of income. This is clear from the analysis of the Gini index and the distribution of the elderly in regions with less employment and income, as revealed by the FMDI employment and income statistic. In more economically developed cities, the percentage of elderly persons is lower, corroborating the idea that in cities with greater employment the population is younger and more active in terms of labor. This fact is a national trend across Brazil, proven by research carried out in other states ${ }^{17,18}$.

The present study verified the presence of elderly persons in municipal regions with better levels of education. This can be explained by the significant increase in the percentage of literate elderly, as well as the increased level of education of such individuals ${ }^{15}$. With specific public policies and the rural pension scheme, the possibility of elderly people remaining in rural areas has increased, while the lack of incentives for the younger population makes them seek out large urban cities, generating an accumulation of individuals with lower levels of education in large municipalities ${ }^{19}$.

It was observed that more older elderly persons reside in the Central region of the state of Rio Grande do Norte, confirming that other more economically developed regions are home to younger elderly persons, who may still able to work.

The older elderly persons are more concentrated in cities with an intermediate Total Population. In other words, these elderly persons do not live in small towns, where a phenomenon of the expulsion of the individuals of this age group occurs, possibly due to a lack of social policies, such as adequate health care or even the phenomenon of seeking social support at more advanced ages. Nor are these older elderly persons found in the larger urban centers, possibly because a younger and more economically active population resides in such regions.

The presence of these elderly people, especially in low-income municipal regions, is highly desirable in households, since the incomes of Brazilian elderly people, including those related to work and retirement, represent an increasing share of the composition of income per household and played an important role in reducing poverty ${ }^{20}$. National PNAD data from 2011 show that around $30 \%$ of the elderly interviewed were economically active. When stratified by region of residence, $16 \%$ lived in rural areas, of whom more than half were economically active, while only $25 \%$ of the elderly in urban areas were economically active. In other words, the elderly living in rural environments remain in paid work longer than the urban elderly ${ }^{15}$.

In the study of population aging, attention must be paid to migratory flows, especially in rural areas, as de-ruralization continues to mark Brazilian territorial structure, with evident regional differences. It should be considered that the rural population varies by region and that the decrease or increase of the migratory flow of this group has a variable impact on total age structure ${ }^{20}$. The present study did not evaluate migratory flow variables. Studies are therefore needed to quantify and evaluate this migratory flow to establish robust relationships between population aging and population migrations.

The selective nature and masculinization of the population exodus and aging are not isolated phenomena and have a strong social influence. The understanding of this dynamic and related factors is important to modify, ameliorate and adapt the current framework to future perspectives. Public policies are therefore needed that consider these new realities ${ }^{19}$.

\section{CONCLUSION}

Population aging in the municipal regions of Rio Grande do Norte is related to the size of their populations, with those of intermediate size exhibiting the strongest associations, as well as the area where the municipal region is located. This relationship becomes more evident in the municipal regions of the central mesoregion of the state. In addition, municipal regions with older populations were associated with favorable educational levels and unequal income distribution. 


\section{REFERENCES}

1. Miranda GMD, Mendes ACG, Silva ALA. O envelhecimento populacional brasileiro: desafios e consequências sociais atuais e futuras. Rev Bras Geriatr Gerontol. 2016;19(3):507-19.

2. Alves DSB, Barbosa MTS, Caffarena ER, Silva AS. Caracterização do envelhecimento populacional no município do Rio de Janeiro: contribuições para políticas públicas sustentáveis. Cad Saúde Coletiva. 2016;24(1):63-9.

3. Vasconcelos AMN, Gomes MMF. Transição demográfica: a experiência brasileira. Epidemiol Serv Saúde. 2012;21(4):539-48.

4. Küchemann BA. Envelhecimento populacional, cuidado e cidadania: velhos dilemas e novos desafios. Soc Estado. 2012; 27(1):165-80.

5. Veras RP. Envelhecimento populacional contemporâneo: demandas, desafios e inovações. Rev Saúde Pública. 2009;43(3):548-54.

6. Santana JA. A Influência da migração no processo de envelhecimento de Minas Gerais e suas regiões de planejamento [dissertação]. Belo Horizonte: Universidade Federal de Minas Gerais; 2002.

7. Miranda GMD, Mendes ACG, Silva ALA. Desafios das políticas públicas no cenário de transição demográfica e mudanças sociais no Brasil. Interface Comum Saúde Educ. 2017;21(61):309-20.

8. Anderson MIP. Saúde e condições de vida do idoso no Brasil. Textos Envelhecimento. 1998;1(1):7-22.

9. Kinsella KG. Future longevity-demographic concerns and consequences. J Am Geriatr Soc. 2005;53(9):299-303.

10. Instituto Brasileiro de Geografia e Estatística. Censo Demográfico 2010 [Internet]. Rio de Janeiro: IBGE; 2010 [acesso em 07 maio 2013]. Disponível em: http://www.censo2010.ibge.gov.br.
11. Instituto Brasileiro de Geografia e Estatística. Indicadores Sociais Mínimos. Conceitos [Internet]. Rio de Janeiro: IBGE; 2013 [acesso em 07 maio 2013]. Disponível em: http://www.ibge.gov.br/ home/estatistica/populacao/condicaodevida/ indicadoresminimos/conceitos.shtm.

12. Programa das Nações Unidas para o Desenvolvimento. Atlas do Desenvolvimento Humano no Brasil [Internet]. Sem local: PNUD; [2013?] [acesso em 07 maio 2013]. Disponível em: http://www.pnud.org.br/Atlas.aspx?view=atlas.

13. Carvalho JAM, Brito F. A demografia brasileira e o declínio da fecundidade no Brasil: contribuições, equívocos e silêncios. Rev Bras Estud Popul. 2013;22(2):351-69.

14. Moreira MM. Envelhecimento da população brasileira e migrações. Polít Públicas Soc. 2003;1(5):7-16.

15. Instituto Brasileiro de Geografia e Estatística. Pesquisa nacional por amostra de domicílios: síntese de indicadores 2011. Rio de Janeiro: IBGE; 2012.

16. Lima DV, Matias PJ. A dinâmica demográfica e a sustentabilidade do regime geral de previdência social brasileiro. Rev Adm Pública. 2014;48(4):847-68.

17. Sampaio AR, Miotto MHMB, Barcellos LA. O estado do Espírito Santo sob a ótica da transição demográfica. UFES Rev Odont. 2008;10(1):5-12.

18. Martin GB, Cordoni Júnior L, Bastos YGL. Aspectos demográficos do processo de envelhecimento populacional em cidade do sul do Brasil. Epidemiol Serv Saúde. 2005;14(3):151-8.

19. McLigeyo SO. Ageing population in Africa and other developing communities: a public health challenge calling for urgent solutions. East Afr Med J. 2002;79(6):281-3.

20. Campos MB. Características demográficas e a voluntariedade da migração. Rev Interdiscipl Mobil Hum. 2015;23(45):273-90. 